\title{
Esperanças e desventuras de escravos e libertos em Vitória e seus arredores ao final do século XIX
}

Geraldo Antonio Soares

UFES

\section{RESUMO}

Neste trabalho examinamos 43 registros de cartas de liberdade, referentes às alforrias de 52 escravos da Freguesia de São João de Cariacica, Termo de Victória, Província do Espírito Santo, no período entre 1872 e 1887. A escolha desse período se deu pelo fato de estarmos nos propondo a examinar o período final da escravidão, mais especificamente a partir da promulgação da Lei do Ventre Livre, em 28 de setembro de 1871, até a abolição, em 1888. Apesar de se tratar de uma pequena amostra, foi possível uma análise comparativa do perfil desses libertos com outras pesquisas mais amplas sobre alforrias no Brasil. Tivemos uma idéia mais precisa a respeito dos significados da liberdade para escravos e libertos a partir da análise de dois inquéritos policiais nos quais as esperanças e desventuras em relação à liberdade puderam ser claramente percebidas.

Palavras-Chave: Escravos; Libertos; Província do Espírito Santo.

\section{ABSTRACT}

In this work we examine 43 registers of freedom letters, referring to the releases of 52 slaves of the Freguesia de São João de Cariacica, Termo de Victória, Province of Espírito Santo, in the period between 1872 and 1887 . This period was chosen because we are interested in examining the last period of the slavery, more specifically from the promulgation of the Lei do Ventre Livre, in September $28^{\text {th }}$ 1871, until the abolition, in 1888. A comparative analysis between the profile of these former-slaves and the results of other researches was possible, although we worked with a small sample. We obtained a clear idea regarding the meanings of freedom among slaves and former-slaves from the analysis of two police inquests in which the hopes and frustrations in relation to the freedom could have been perceived clearly. Keywords: Slaves; Former-slaves; Province of Espírito Santo. 
Em 18 de fevereiro de 1884 registrou-se na Freguesia de São João de Cariacica, Termo de Victoria, em um Livro de Escrituras e Procurações, uma Carta de Liberdade. Tal carta se referia à liberdade de Joanna, 36 anos mais ou menos, parda, solteira, filha natural de Angélica, falecida. Podemos constatar ainda que se tratava de uma carta de liberdade condicional e en causa mortis, na qual Manoel Pereira dos Passos libertava uma sua escrava nos seguintes termos:

a qual Joanna de minha livre e espontânea vontade depois de meu falecimento concedo sua liberdade na metade somente, afim de que possa nesse dia de meu falecimento entrar no gozo de sua liberdade na parte da metade como se fosse de ventre livre, sem que ninguém a possa chamar à escravidão em virtude desse meu escrito. ${ }^{1}$

Um senhor de escravos que liberta uma sua escrava somente pela metade, e ainda assim com a condição implícita de ela ter de acompanhá-lo ao longo de sua vida. Que diz ainda na carta que sua escrava entrará no gozo de sua liberdade somente pela metade, explicitando seu zelo ou preocupação em impedir que a liberta, pela metade, não seja reescravizada pela outra metade. Nossa primeira reação a um documento como esse é ver aí apenas cinismo e falta de sensibilidade por parte de Manoel Pereira dos Passos, e mesmo pensar que uma promessa de liberdade nesses termos não significaria nada para Joanna. No entanto, a escolha proposital desse caso para abrir este trabalho tem a intenção de mostrar justamente que a situação não era tão simples assim. A realidade da escravidão era mais complexa do que ela se nos apresenta à primeira vista, e a última coisa que devemos fazer é nos enveredarmos por qualquer espécie de julgamento moral sobre as situações vividas pelos nossos personagens históricos.

Examinaremos neste trabalho 43 registros de cartas de liberdade, referentes às alforrias de 52 escravos no período entre 1872 e 1887. A escolha desse período se deu em função de disponibilidade de fontes e pelo fato de estarmos nos propondo a examinar o período final da escravidão, mais especificamente a partir da promulgação da Lei do Ventre Livre, em 28 de setembro de 1871. Naquele momento, o novo ordenamento jurídico vem evidenciar que a causa da emancipação dos escravos estava avançando de forma decisiva na sociedade brasileira. Por se tratar de uma pequena amostra, não nos deteremos no perfil desses libertos mediante uma análise quantitativa dos dados. Mas é possível uma análise comparativa desse perfil com outras pes- 
quisas mais amplas sobre alforrias no Brasil, para termos uma idéia a respeito da representatividade de nossa amostra.

A Freguesia de São João de Cariacica, juntamente com as freguesias de São José do Queimado, São João de Carapina e Nossa Senhora do Rosário do Espírito Santo, localizava-se nos arredores da paróquia de Nossa Senhora da Victoria. Na capital Vitória havia 1.001 escravos, sendo 450 homens e 551 mulheres, para uma população de 3.360 livres em 1872. No conjunto das freguesias em torno de Vitória havia 2.716 escravos, sendo 1.393 homens e 1.323 mulheres, para uma população de 8.899 livres. Ou seja, tanto em Vitória como em seus arredores, tínhamos uma relação próxima de um para três entre escravos e livres. A Freguesia de São João de Cariacica possuía um total de 1.174 escravos, sendo 599 homens e 575 mulheres. $^{2}$

Os libertos da Freguesia de São João de Cariacica que constam nos registros de carta de liberdade que pesquisamos se distribuíam da seguinte forma por faixa de idade: entre 0 a 11 anos havia apenas uma pessoa; entre $12 \mathrm{e}$ 35 anos, 15 pessoas; entre 36 e 50 anos, 11 pessoas; entre 51 e 60 anos, apenas uma pessoa; com mais de 60 anos, novamente apenas uma pessoa. Para 23 libertos não havia registro de idade. Dos 29 libertos para os quais havia registro de idade, em 13 o registro vinha acompanhado da expressão "mais ou menos". Essas imprecisões nos registros nos recomendam cautela na análise desses dados por faixa etária.

Tratando da dificuldade em se determinar a idade de escravos alforriados, Stuart Schwartz observa que os críticos tradicionais da emancipação no Brasil argumentam com freqüência que haveria uma tendência de alforriarem-se escravos velhos ou enfermos para que assim os senhores se livrassem dos custos de manutenção desses escravos improdutivos. ${ }^{3}$ Um exemplo de abordagem convencional da alforria no Brasil é o trabalho de A. J. R. RussellWood. Esse historiador incorre em alguns lugares comuns sobre o tema, como quando afirma que os senhores permitiam aos escravos comprar a liberdade porque a idade, a doença ou alguma lesão os impediam de trabalhar, ou ainda que "até a mais apressada olhadela pelas coleções de cartas de alforria revela a freqüência da frase 'inútil para qualquer forma de trabalho'”. ${ }^{4}$ Não encontramos em nossas fontes nenhum caso em que se especificasse o estado de saúde do liberto, como não encontramos a expressão aqui citada. Mas nossas informações sobre idade dos libertos, reunidas na Tabela 1, nos esclarecem alguns aspectos, embora deixem outros obscuros.

A maioria de nossos libertos situa-se naquelas que poderíamos chamar de faixas de idade mais produtivas dos escravos, as faixas entre 12 e 50 anos, 
considerando no caso que o escravo começava a trabalhar cedo e trabalhava ainda quando já podia ser considerado idoso. Entre as trinta mulheres libertas, 18 ou 60 por cento delas têm entre 12 e 50 anos. No caso dos homens, dos 22 libertos, oito, ou 36,36 por cento deles, estão nessa faixa de idade, sendo superados apenas pelos 12 homens para os quais não consta a idade em nossos registros.

Tabela 1 - Distribuição etária de escravos alforriados por gênero, preço e condição da alforria na Freguesia de São João de Cariacica, entre 1872 e 1887

\begin{tabular}{|c|c|c|c|c|c|c|}
\hline Idades & Homens & Mulheres & Gratuitas & Pagas & Condicionais $^{\star}$ & Incondicionais \\
\hline $0-11$ & 1 & - & - & 1 & - & 1 \\
\hline $12-35$ & 4 & 11 & 7 & 8 & 1 & 14 \\
\hline $36-50$ & 4 & 7 & 4 & 7 & 4 & 7 \\
\hline $51-60$ & - & 1 & - & 1 & - & 1 \\
\hline+ de 60 & 1 & - & - & 1 & - & 1 \\
\hline Desconhecida & 12 & 11 & 16 & 7 & 12 & 11 \\
\hline Total & 22 & 30 & 27 & 25 & 17 & 35 \\
\hline
\end{tabular}

* Condições outras que não sejam pagamento pela alforria em dinheiro, como prestação de serviços até a morte do senhor, por exemplo.

Fonte: Registros de 43 cartas de liberdade envolvendo 52 libertos originários do Cartório Sede da Freguesia de São João de Cariacica, no período entre 1872 e 1887, localizados no Cartório Ronconi, em Cariacica (ES).

Nosso problema é justamente esse grande número de libertos para os quais não sabemos a idade, por não ter sido ela informada quando do registro da alforria, por alguma razão que não temos como conhecer. Uma razão possível é justamente serem esses libertos idosos, por terem entrado no país antes da primeira lei que proibia o tráfico, a de 1835. Mas também podem ser muito jovens, se entraram no país depois da lei de proibição do tráfico, de 1851. Para doze dos 23 libertos cuja idade não é informada, também não se informa a nacionalidade. Para um liberto consta ser ele de nação angola. Há também duas cartas que libertam famílias, totalizando dez pessoas. Só poderíamos concluir pela tendência a se libertar escravos idosos se incluíssemos entre os de mais de 60 anos aqueles de idade não informada, o que a diversidade de situações desses libertos nos registros não autoriza. 
Temos apenas uma criança entre os 52 libertos. Trata-se de Antônio, 7 anos, pardo, cujo senhor era Ignácio João Rodrigues da Annunciação. Sua alforria foi obtida por $500 \$ 000$ (quinhentos mil réis), um valor acima da média do conjunto das alforrias pagas. Consta ainda no registro que "o liberto era filho 'pertencente' de Rita Maria da Annunciação", ${ }^{5}$ o que nos leva a presumir que sua mãe era uma liberta que havia sido escrava do mesmo senhor de Antônio.

Temos também apenas um homem com mais de 60 anos entre os 52 libertos. Seu nome era José, idade 69 anos, pardo. Sua liberdade foi obtida pela quantia de $100 \$ 000$. Em sua carta de alforria consta ainda, laconicamente, depois de 69 anos de escravidão, "podendo desde já ir para onde lhe convier". 6

Portanto não observamos em nossas fontes aquilo que Peter Eisenberg constata em suas pesquisas sobre alforrias em Campinas, ou seja, no nosso caso não havia uma tendência de favorecimento dos muito jovens e dos muito velhos quando da concessão da alforria. ${ }^{7}$

Entre os 52 alforriados que pesquisamos havia 22 homens e 30 mulheres, representando os homens 42,3 por cento dos escravos alforriados. Essa maioria de mulheres alforriadas acompanha as tendências verificadas em outros estudos envolvendo a relação entre alforria e gênero no Brasil escravista. Examinando 13.127 cartas de alforria registradas nos tabelionatos da Bahia no período entre 1819 e 1888, Kátia M. Q. Mattoso observa que a porcentagem masculina oscila entre um mínimo de 34,7 e um máximo de 47,8 por cento, mantendo-se bastante estável a proporção em torno de um homem para cada duas mulheres, durante todo o período. ${ }^{8}$ Para essa historiadora o maior número de mulheres alforriadas se deve possivelmente ao fato de elas serem consideradas menos produtivas e possuírem menor resistência física, além de seu preço ser menor que o do escravo do sexo masculino. A preferência por alforriar mulheres guardaria então relação com a própria preferência pela aquisição de escravos homens. Com base em nossas fontes não temos como encontrar nenhuma outra explicação para essa preferência. Não dispomos, todavia, de elementos objetivos para afirmar que as razões são mesmo essas.

Segundo Peter Eisenberg, em Campinas a partir da década de 1870 e, sobretudo na década de 1880 , as alforrias gratuitas se tornaram majoritárias, primeiramente para os escravos e depois para as escravas. Isto por duas razões básicas: expectativas pessimistas a respeito da sobrevivência da escravidão e queda rápida no preço dos escravos. ${ }^{9}$ Em nossas fontes observamos um equilíbrio em relação ao número de 27 alforrias gratuitas, comparadas com as 25 alforrias pagas durante o período. Como dispomos dos preços das al- 
forrias, consideramos relevante comparar esses preços com os preços médios de escravos na província do Espírito Santo no mesmo período. Para tal, faremos uso de um levantamento de preços de escravos realizado por Vilma P. F. Almada com base em inventários em cartórios de Vitória e Cachoeiro do Itapemirim. Seus dados são sobre escravos com idade entre 15 e 29 anos e cobrem o período 1850-1887. Com esse conjunto de informações, montamos a Tabela 2.

Tabela 2 - Preços médios de escravos nos municípios de Vitória e Cachoeiro de Itapemirim, e de alforrias na Freguesia de São João de Cariacica

\begin{tabular}{c|c|c|c|c|c|c|c|c|c|c}
\hline & \multicolumn{2}{|c|}{$\begin{array}{l}\text { Número de escravos e preço médio (mil réis) } \\
\text { Vitória e Cachoeiro de Itapemirim }\end{array}$} & \multicolumn{3}{|c|}{$\begin{array}{l}\text { Número de alforrias pagas e preço } \\
\text { médio (mil réis) em Cariacicarias }\end{array}$} & $\begin{array}{l}\text { Alforias } \\
\text { gratuitas }\end{array}$ \\
\hline Anos & Inventários & Homens & Preço & Mulheres & Preço & Homens & Preço & Mulheres & Preço & \\
\hline $1872-1875$ & 11 & 16 & 1.284 & 23 & 1.074 & 6 & 445 & 6 & 276 & 4 \\
$1876-1880$ & 17 & 39 & 1.343 & 28 & 1.174 & 3 & 500 & 2 & 250 & 11 \\
$1881-1885$ & 13 & 30 & 949 & 23 & 700 & 1 & 300 & 1 & 400 & 9 \\
$1886-1887$ & 6 & 26 & 757 & 15 & 575 & 2 & 350 & 4 & 175 & 3 \\
\hline Total & 47 & 111 & 1.083 & 89 & 881 & 12 & 399 & 13 & 275 & 27 \\
\hline
\end{tabular}

Fontes: Registros de 43 cartas de liberdade envolvendo 52 libertos originários do Cartório Sede da Freguesia de São João de Cariacica, no período entre 1872 e 1887, localizados no Cartório Ronconi, em Cariacica (ES); ALMADA, Vilma P. F. Escravismo e transição: o Espírito Santo (1850/1888). Rio de Janeiro: Graal, 1984. p.129.

Estes dados devem ser vistos com ressalvas, porque, se pretendermos ter uma idéia mais precisa tanto do preço dos escravos como das alforrias, tais preços teriam de ser considerados levando em conta a idade, o estado de saúde e a qualificação dos escravos, informações de que não dispomos. Mas, apesar de todos os problemas, nossos dados nos mostram que de fato há uma diferença significativa no preço das alforrias das mulheres escravas em relação aos homens. A única exceção é o período 1881-1885, mas que não é significativa por termos apenas um escravo e uma escrava alforriados nesse período.

Ao compararmos os preços das alforrias com o preço dos escravos mesmo que estes sejam jovens —, o mais significativo é que a diferença entre esses conjuntos de preços é muito grande. O preço médio dos escravos é sempre mais que o dobro do preço das alforrias. No caso das mulheres tal diferença é ainda maior, o que confirma a idéia de que as mulheres obtinham me- 
lhores condições de alforria que os homens. Mas o fato de o preço das alforrias nunca chegar à metade do preço dos escravos nos leva a concluir que o senhor, ao alforriar um escravo, não visava recuperar seu preço ou fazer um bom negócio. O preço da alforria envolvia um deságio que representava um prêmio, um benefício ou uma recompensa para o escravo.

Era muito comum aparecer, nas cartas de alforria, a expressão "bons serviços prestados" como motivo para se conceder a alforria. Em nossas fontes, esse motivo para a alforria é explicitado em doze cartas de liberdade. Usavase essa expressão certamente para se expressar as qualidades de submissão, lealdade, fidelidade, dedicação e obediência. Tais qualidades faziam um bom escravo e o tornavam merecedor da liberdade. Mas, como assinala Stuart Schwartz,

está claro, entretanto, que 'bons serviços' não eram motivo muito importante para a emancipação, mas, eram, pelo contrário, uma espécie de 'pré-requisito' ou exigência mínima. Isto acontecia especialmente quando o senhor não recebia pagamento pela libertação do escravo. ${ }^{10}$

Na concessão da carta de alforria por dinheiro havia certamente interesse, mas não apenas interesse. Temos de ser cuidadosos e levar em conta que

as explicações tradicionais sobre a emancipação têm sido em grande parte expressas como extremos opostos de humanitarismo culturalmente determinado, ou freqüentes reações desumanas e considerações puramente econômicas. Não há necessidade de dividir essas explicações em categorias distintas. Os imperativos econômicos da escravidão sempre operavam num contexto cultural. (Schwartz, 2001, p.211)

Em nossas fontes encontramos vários casos de libertos que obtinham sua liberdade pagando por ela, mas constando também na carta que os motivos para a alforria foram os bons serviços prestados. Uma carta de liberdade podia ser concedida ao mesmo tempo por amor, interesse e recompensa por bons serviços. Esses sentimentos são apenas aparentemente contraditórios, e o senhor não estava sendo cínico ao expressá-los todos simultaneamente. Examinando 356 cartas de alforria envolvendo a libertação de quatrocentos escravos, no período entre 1684 e 1707, na Bahia, Ligia Bellini chega à conclusão de que "sempre se procura distinguir e situar em pólos às vezes opostos o que é feito por amor ou fé do que é feito por dinheiro. Nas cartas estudadas, 
estes fatores parecem quase que complementares". ${ }^{11}$ Acrescentaríamos que pensar que os senhores ou agiam por amor e gratidão, ou por interesse, seria vê-los carregados de maniqueísmo.

Em 15 de setembro de 1884, Jesuína Pereira Pinto do Sacramento, que não sabia ler ou escrever (carta assinada a rogo), liberta sua escrava Lauvirgides, 14 anos, filha natural de Gertrudes, liberta, pela quantia de 400\$000, entregue pelo Alferes João Barbosa das Neves, e alega que lhe concede a liberdade "em recompensa aos serviços que lhe tem prestado a dita escrava e pela amizade que devota a ela". Acrescenta ainda que "assim o fez, podendo já entrar no gozo de sua liberdade, como se de ventre livre nascesse". ${ }^{12}$

Se podemos ter dificuldade em entender ou aceitar que alguém liberte uma escrava, cobrando um valor acima da média do que se cobrava pelas alforrias de mulheres, e ainda assim alegue que o faz pela amizade que devotava à escrava, há também casos em que se cobra um preço igualmente elevado pela alforria, mas se expressa certo constrangimento por tal ato. Em 28 de outubro de 1886 registra-se a carta de liberdade em que Theresa Maria de Jesus libertava Caetano, crioulo, 30 anos mais ou menos, alegando os seguintes motivos: "tendo recebido do escravo a quantia de $600 \$ 000$ para minha manutenção, visto não ter curso algum por haver sido abandonada por meu marido Manoel Pinto de Almeida e Silva". ${ }^{13}$

Os senhores de escravos, como os próprios escravos, eram dotados de traços de personalidade complexos, como o são os nossos, e que não podem ser reduzidos simplesmente a uma bondade ou maldade inerentes. Além disso, nunca é demais lembrar que a escravidão não era moralmente condenada nas décadas de 1870 e 1880 da mesma forma que o é por nós, hoje. Como adverte Eduardo Silva, "a questão da 'liberdade' tem sido mal colocada sempre que o historiador confunde o seu mundo - onde a escravidão é condenada de um ponto de vista moral - com o mundo do escravo, onde a instituição fazia parte da ordem natural das coisas". ${ }^{14}$

O pagamento da alforria pelo escravo, mesmo por uma quantia que representava apenas uma parte de seu valor real, também nos parece revelar o que poderíamos chamar de um propósito pedagógico por parte do senhor em relação a seu escravo. A impressão que fica é a de que o senhor fazia questão de mostrar ao seu antigo escravo, não apenas sua generosidade em recompensá-lo pela obediência e fidelidade, como também que tudo tem um preço. Os casos de liberdade obtida em partes podem ser vistos por esse prisma.

Em 12 de abril de 1873 registra-se uma carta de liberdade em que Erculano da Costa Muniz (assinado a rogo) liberta em um terço o escravo Manoel 
mediante o pagamento da quantia de $190 \$ 000$ pelo motivo de "segurança de liberdade, ficando o mesmo meu escravo gozando desde hoje de sua liberdade desta parte acima mencionada". ${ }^{15}$ Já no ano de 1878, registra-se uma carta de liberdade em que Luiza Maria da Conceição liberta gratuitamente sua escrava Galdéria, parda, 24 anos, filiação desconhecida, capaz de trabalhos na lavoura, com a observação de que a libertava em três partes porque de uma parte foi liberta quando faleceu seu marido. ${ }^{16}$

Lendo essas cartas em que se libertava como que a prestações, não há como não nos lembrarmos dos escritos de Perdigão Malheiro e sua insistência na necessidade da emancipação gradual, seja para preparar melhor o escravo para a liberdade, seja para preservar a autoridade moral dos senhores. ${ }^{17}$ Nessa defesa da emancipação gradual, a alforria condicional, ou seja, aquela em que a liberdade é concedida em troca de um compromisso firmado pelo liberto em troca de alguma prestação de serviço, tem um importante papel na renovação das relações de poder naquela sociedade. Existe toda uma discussão na historiografia sobre a escravidão no Brasil: o liberto condicional entrava no gozo de sua liberdade de imediato, ou tal liberdade somente seria uma realidade para ele quando se cumprisse a condição? Isso poderia levar anos quando da morte do senhor, por exemplo, condição muito freqüente nas cartas de alforria. O próprio Perdigão Malheiro adota uma posição intermediária, afirmando que o estatuto do liberto condicional era semelhante ao do menor ainda não emancipado, pelo qual o senhor ainda responderia até que a condição se cumprisse.

Havia a respeito do estatuto do liberto condicional algo mais que uma querela jurídica. Quando um escravo recebia uma carta de liberdade condicional, esse liberto sob condição criava toda uma expectativa de que sua situação havia mudado. $\mathrm{O}$ mesmo poderíamos dizer em relação ao senhor, já que se ele concedeu a carta de liberdade foi com algum objetivo em mente. Em nossas fontes encontramos algumas cartas de liberdade condicional, e em todas elas a condição era de que o liberto continuasse prestando seus serviços ao libertador até a morte deste. Encontramos dois tipos de carta: a de liberdade condicional propriamente dita e a de liberdade en causa mortis.

Em 25 de abril de 1873 registra-se a carta de liberdade de Luiz, escravo de Maria da Victoria, viúva de Manoel Gonçalves (assinado a rogo), alegando-se os motivos de segurança de liberdade e de merecimento de um benefício pelos bons serviços prestados. Declara ainda "que quando de minha morte ficará liberto como que de ventre livre nascesse, não podendo nenhum de meus herdeiros se oporem a esta minha disposição". ${ }^{18} \mathrm{Na}$ data de 16 de de- 
zembro de 1876 consta o registro de liberdade de Francisco, pardo, brasileiro, 50 anos mais ou menos, alforriado por Ana Maria Pinto (assinado a rogo pelo neto). Registra-se também a disposição de que "o dito escravo fica liberto, porém com a condição de me acompanhar durante a minha vida e depois da minha morte irá para onde lhe convier". ${ }^{19}$ A plena liberdade de Francisco só viria quando da morte de sua antiga senhora. Talvez ele nutrisse uma expectativa de não ter de esperar muito, já que é o neto de Ana Maria Pinto quem assina a carta de liberdade por ela. É possível também que a própria libertadora não tivesse grandes ilusões quanto ao tempo que ainda lhe restava neste mundo, já que se sente no direito de cobrar de imediato a quantia de 200\$000 pela liberdade que concede a Francisco.

Se Francisco teve de pagar de imediato por sua carta de alforria condicional, já a Quirino foi dada a oportunidade de pagá-la a termo. Em 29 de dezembro de 1877 é registrada uma carta de liberdade em que Josefina Maria Magdalena da Cunha (assinado a rogo) liberta seu escravo Quirino, fula, 45 anos, com as seguintes e detalhadas condições:

desde já o confere plena liberdade por ser de sua espontânea vontade com a condição de não poder o dito liberto Quirino se afastar da companhia da libertadora, durante sua existência, ficando o dito Quirino obrigado a apresentar na hora de sua morte a quantia no seu funeral de $200 \$ 000$, que será empregada a dita quantia no seu funeral, o que não gozará de sua liberdade sem que satisfaça as condições mencionadas na dita escritura que considero valiosa, e gozará da dita liberdade depois de minha morte como se nascesse de ventre livre, não podendo meus herdeiros ter ação alguma sob o dito escravo Quirino, e por ter assim assentado sem contradição alguma e ser de combinação com todos meus filhos que também assinam. ${ }^{20}$

Josefina Maria Magdalena da Cunha não se contentava em continuar contando com os serviços de Quirino enquanto fosse viva. Queria receber algo depois de seu falecimento. Ao que tudo indica, trata-se de uma senhora de uma sovinice extrema. Para se livrar de tudo isso, Quirino, certamente pensando que não lhe restava alternativa, concordou com os termos. Mas as relações entre seres humanos, e é disso que se trata, nunca são simples. Kátia M. Q. Mattoso localiza em suas fontes em cartórios da Bahia, em um testamento de uma liberta, um legado inusitado. Em 30 de agosto de 1805, Quitéria de Assumpçam, africana de nação jeje, idade desconhecida, de profissão lavradora e vendedora ambulante, fez redigir seu testamento em sete páginas. Qui- 
téria foi sucessivamente escrava de Maria de Assumpçam e de Silvestre de Araújo Oliveira, de quem comprou a liberdade por $150 \$ 000$. Não tinha filhos e nomeia como herdeiro um de seus irmãos, Luiz Teixeira. Seus modestos bens incluíam dois escravos adultos, Francisco, nação angola, e Rita, nação jeje. Entre os legados de Quitéria consta:

a meu crioulinho Manuel e sua irmã Maria, filhos da escrava Joaquina, hoje liberta, $8 \$ 000$ para que sejam divididos entre eles e por este ato renovo sua liberdade para que ficam [sic] na companhia de meu segundo testamenteiro [seu outro irmão que se chama Manoel Velozo] ... e declaro que deixo ao Senhor Silvestre de Araújo Oliveira, do poder do qual me libertei pela importância de $150 \$ 000$, dois mil réis, em sinal de reconhecimento e peço-lhe que me perdoe de não poder fazer mais. ${ }^{21}$

Se Josefina Maria Magdalena da Cunha exigia receber uma quantia significativa de Quirino mesmo depois de sua morte, já o antigo senhor de Quitéria, Silvestre de Araújo Oliveira, iria receber em legado uma pequena quantia que a própria Quitéria faltou apenas declarar que, embora pequena, era de coração.

As cartas de liberdade de Francisco e Quirino explicitam que a liberdade é concedida de imediato e o acompanhamento até a morte das senhoras é uma condição. O mesmo não ocorre com a carta concedida a Gertrudes e seu filho Manoel. Em sua carta de liberdade conjunta, registrada em 22 de setembro de 1883, consta que Joanna Pereira de Jesus os libertava, mas não de imediato, como sugerem os seguintes termos que constam no registro: "os quais poderão gozar logo que eu faleça, sem que ninguém os possa jamais chamar à escravidão sob qualquer pretexto que seja".22

Mais explícita ainda é a carta de liberdade conjunta em que Rita Maria de Jesus libertava oito escravos. Em $1^{\circ}$ de maio de 1877 consta o registro de que essa senhora libertava os seguintes escravos: Jesuíno e seus filhos Francisca, Manoella e Filomeno; Manoel e João, filhos de Maria; Joanna e seu filho José. Estes eram mulatos e pretos (Joanna e seu filho). Como disposição constava: "Por minha morte deixo todos eles libertos e forros, para que entrem no gozo de sua pessoa e direitos, como se de ventre livre nascessem. Quanto aos escravos Filomeno e Maria, a liberdade que lhes confiro é somente pela metade de seus valores, porquanto na outra metade já são forros, quanto provém aos demais escravos a liberdade é no seu todo". ${ }^{23} \mathrm{O}$ registro reforça ainda que a liberdade é concedida en causa mortis. 
A diferença entre uma carta de alforria condicional e uma carta de alforria en causa mortis é que na primeira o liberto entra na fruição ou gozo da liberdade de imediato, mesmo tendo de cumprir a condição. No caso da carta de liberdade en causa mortis, a liberdade é de fato apenas prometida. A concessão de uma carta de alforria, em ambos os casos, partia de uma necessidade objetiva de reforço nas relações de poder e de dependência, relações estas que, no caso, não deveriam estar muito consolidadas. $\mathrm{O}$ que se pretendia era que o agora liberto ou ainda escravo, no caso das alforrias en causa mortis, continuasse ou se tornasse mais submisso e fiel. O problema é que não havia uma grande segurança de que essa submissão e essa fidelidade fossem asseguradas por tais atos. Como Sidney Chalhoub já mostrou muito bem, se alguns libertos atendiam às expectativas de seus antigos senhores, outros se tornavam até mais insubordinados e atrevidos depois de obtida a alforria condicional. ${ }^{24}$ Acreditamos que eram aqueles senhores mais inseguros quanto ao tipo de comportamento que seus antigos escravos, e agora libertos condicionais, passariam a adotar, que optavam pela carta de alforria en causa mortis, por representar esta efetivamente apenas uma promessa de liberdade, sem qualquer ambigüidade.

E os escravos libertados en causa mortis, se contentavam com o que pode nos parecer tão pouco? Permaneciam ou se tornavam mais submissos a partir de então? Não temos respostas para estas perguntas, mas o que nos parece certo é que a liberdade, mesmo que apenas como promessa, ou como uma esperança, era algo pelo qual valia a pena lutar. Afinal de contas, não é à toa que a expressão "como se de ventre livre nascesse", tão comum nas cartas de alforria (em nossas fontes essa expressão aparece em onze cartas de liberdade), parece estar associada simbolicamente a um renascimento, como lembra Lígia Bellini. ${ }^{25}$

Num trabalho que peca pelo excesso de generalizações e no qual a autora se revela mais pessimista que suas fontes, Mary C. Karasch afirma:

A longa batalha para conquistar a alforria, apesar do baixo status social das pessoas libertas, sugere muito sobre as condições terríveis da escravidão ... O que esperava boa parte dos libertos, em especial as mulheres idosas, não era o sonho dourado da liberdade, mas o pesadelo da pobreza. Muitos haviam exaurido suas economias no esforço de comprar a liberdade e suas condições de vida material deterioravam rapidamente depois que deixavam a casa do dono. Este capítulo [intitulado "A carta de alforria"] conclui, portanto, com um quadro deprimente do que aguardava os ex-escravos, em especial depois de $1850 .^{26}$ 
Dado o pessimismo generalizado aí retratado, não ficamos sabendo o que a autora considerava pior, a condição de escravo ou a de liberto. Mas logo a seguir essa historiadora passa a listar as vantagens da condição de liberto: direito de casar-se e constituir família sem medo de ser separado; direito à propriedade, inclusive de escravos; direito de ficar com a totalidade do salário que obtinham no ganho; mais opções de moradia; uma mobilidade física maior que a dos cativos. Embora tenha grande dificuldade em superar a idéia, que nos parece pré-concebida, a respeito das condições terríveis da escravidão e da herança igualmente terrível do cativeiro para o liberto, Mary Karasch acaba por admitir, até com certo exagero, que

os escravos que pediam alforria, no entanto, faziam-no com freqüência por motivos outros que não a mobilidade social ascendente. Eles achavam que a liberdade valia as incertezas e desvantagens que muitas vezes a acompanhavam. Regalavam-se tanto com a liberdade que tentavam espalhar sua mensagem entre os antigos companheiros de cativeiro. (Karasch, 2000, p.474)

Os escravos e libertos sabiam que havia de fato grandes vantagens na liberdade, vantagens estas que estavam associadas aos próprios significados da liberdade no Brasil escravista. Hebe Maria Mattos sintetiza muito bem como se construíam tais significados:

Parece-me bem mais razoável supor que, na vigência da escravidão, as expectativas de liberdade, que se abriam aos nascidos livres despossuídos e ao sonho de liberdade dos escravizados, foram culturalmente construídas no interior da sociedade escravista e estiveram a ela integrados. Desse modo, 'livres pobres' ou escravos (uma vez que socializados enquanto tais) agiam socialmente a partir dos códigos culturais correntes naquela sociedade, mesmo que reinterpretados a partir de suas posições sociais específicas. ${ }^{27}$

O que Hebe Maria Mattos considera como os pilares básicos da experiência de liberdade ao longo do século XIX eram a mobilidade, a família e a propriedade, $\mathrm{e}$,

neste contexto, o direito de ir e vir era exercido em busca de laços, a família era constituída face à Igreja (e não ao Estado), que respondia também pela separação de bens, em caso de divórcio, e a propriedade era entendida em termos parcelários (direitos de propriedade superpostos) e se estendia até os escravos. (Mattos, 1998, p.283) 
É possível ter uma idéia mais precisa dos significados da liberdade para escravos e libertos a partir de dois inquéritos policiais que pesquisamos no Arquivo Público do Estado do Espírito Santo - Apees, nos quais as esperanças e desventuras em relação à liberdade vêm à tona.

No dia 4 de dezembro de 1872, Antônio Gonçalves Laranja, lavrador e proprietário, residente no lugar denominado Ilha das Pedras, pertencente à Vila do Espírito Santo, sabendo ler e escrever, apresentou queixa contra Angelo Marcellino Pinto, liberto, com 40 anos de idade mais ou menos, casado, lavrador, de nacionalidade brasileira, residente no lugar denominado Paul, na Freguesia de Cariacica. A queixa era de que Angelo Marcellino havia seduzido um seu escravo de nome Ignácio, preto de nação, mais de 50 anos.

Este seria mais um caso de fuga de escravo, vista pelo seu proprietário como sedução para utilização de seus serviços, não fosse uma série de circunstâncias peculiares envolvendo a situação e que assim a tornam de especial interesse para nós.

Comecemos pelo depoimento do Sr. Antônio Gonçalves Laranja. Segundo ele, desde o dia 8 de setembro de 1872 o seu escravo Ignácio estava fugido de sua casa. Foi naquele dia que, aproveitando-se de sua ausência, apresentou-se em sua casa o liberto Angelo Marcellino, acompanhado de um escravo de nome Clemente, pertencente a Sebastião Pinto da Conceição, e "iludindo a um filho dele respondente, de nome Policarpo, de idade de 14 anos, fez este dar um bilhete ao escravo Ignácio para procurar senhor sem consentimento da mulher dele respondente, nem dele". ${ }^{28}$

Pelo depoimento e pela queixa do Sr. Antônio Gonçalves Laranja, ficamos sabendo ainda que a casa de Angelo Marcellino ficava defronte à dele respondente, menos de um quilômetro, apenas separadas as duas casas pelo rio chamado Marinho; que o escravo Ignácio vinha trabalhando para Angelo Marcellino até recentemente, seja colhendo roça de milho seja cuidando de um pequeno canavial, ou mesmo indo, juntamente com Angelo Marcellino, até Vitória conduzindo barcadas de lenha. Diz-nos ainda que tem procurado por todos os meios reaver o seu escravo, e que Angelo Marcellino o tem insultado e que até uma vez, há um mês e meio, esperou a ele Gonçalves Laranja, no caminho, quando voltava de Cariacica, e o atacou acompanhado de Joaquim de Sant'Anna Roza. Em relação a este último episódio, o Sr. Antônio Gonçalves Laranja nos esclarece que não chegou a ser ofendido por Angelo Marcellino e Joaquim de Sant'Anna Roza e sim que Angelo Marcellino “limitou-se a avançar sobre o cavalo em que montava ele respondente armado de cacete ameaçando-lhe e dizendo-lhe: se ainda não estava desenganado de pro- 
curar o escravo Ignácio e que lhe havia de fazer uma desfeita se continuasse a procurar o escravo" ${ }^{29}$

Em seu depoimento Angelo Marcellino diz que conhece o escravo Ignácio, mas que não sabe de seu paradeiro. Ao ser perguntado se o escravo Ignácio não trabalhou em sua casa e terras, fazendo roça de milho, feijão e cana naquele ano, Angelo Marcellino responde:

que é verdade, plantou e que o milho e o feijão o escravo limpou e colheu quando estava em casa de seu senhor e que a cana ainda existe abandonada por não ser tratada, visto ter fugido o escravo depois que fez a colheita do milho no mês de setembro deste ano mais ou menos. ${ }^{30}$

No final de seu depoimento, ao ser perguntado se não tem vindo à cidade vender lenha, acompanhado do escravo Ignácio, Angelo Marcellino dá uma resposta direta e incisiva. Diz ele que

não seria tão estúpido que viesse a esta cidade acompanhado de um escravo cativo e fugido de outrem; e que alguma vez que veio à cidade vender lenha com o dito escravo foi com o consentimento do senhor dele, em canoa dele, quando o escravo estava em casa dele; depois que fugiu, não pode saber aonde ele para, sabendo porém que está fugido. ${ }^{31}$

Talvez tenha sido exatamente esta resposta, de uma segurança inesperada pelo chefe de polícia, que tenha feito com que se registrassem no inquérito os sinais característicos do réu. Tais sinais que caracterizavam Angelo Marcellino eram:

Cor vermelha escura, alto, magro.

Cabelos encarapinhados e grisalhos.

Olhos pardos e vivos.

Nariz achatado.

Bigodes pretos.

Dentes alvos.

Lábios ou beiços finos, barba no queixo.

Rosto comprido.

Mostra ter mais de 45 anos de idade.

Muito fino e esperto e tem os movimentos rápidos. ${ }^{32}$ 
Mesmo se pela última declaração de Angelo Marcellino fique claro que havia certo perigo em vir à cidade - e aqui Vitória aparece como o local urbano por excelência em relação às freguesias e vilas próximas - acompanhado de um escravo fugido, não é o que podemos inferir do depoimento da primeira testemunha no inquérito.

Manoel Pinto Aleixo, de 51 anos de idade, empregado público, casado, morador em Vitória e natural do Porto, em Portugal, sabendo ler e escrever, ao ser perguntado se sabia se o réu vinha constantemente com o escravo Ignácio a esta cidade, conduzindo lenha para aqui vender, declara "que encontrara uma noite o réu presente embarcando no cais Municipal com uma pessoa de cor preta, mas que esta testemunha não a conheceu, ignorando por isso se era escravo essa pessoa, ou livre, e para onde se dirigia". ${ }^{33} \mathrm{O}$ que se observa por esse depoimento é uma dificuldade em se saber da condição de uma pessoa na cidade simplesmente pela sua cor ou ocupação.

Na primeira parte de seu depoimento, Angelo Marcellino admite que o escravo Ignácio trabalhou em suas terras, mas acrescenta um dado novo: Ignácio já ali trabalhava, com o consentimento de seu senhor, antes de ter fugido.

Joaquim de Siqueira Coutinho, de 30 anos de idade, lavrador, casado, morador no lugar denominado Campo Grande, no distrito de Cariacica, natural da própria província, não sabendo ler e escrever, ao ser inquirido sobre os fatos, respondeu que ignorava que o réu ocultasse com fraude o escravo Ignácio, pertencente a Antônio Gonçalves Laranja, e acrescenta que

o que sabe a tal respeito é que antes de abandonar o dito escravo a casa de seu senhor, eximindo-se ao cativeiro, trabalhara nas terras do réu, com licença deste e consentimento do senhor do dito escravo, no sábado e domingo de cada semana, dias em que o dito escravo trabalhava para i. $^{34}$

Mas o depoimento mais esclarecedor a esse respeito é o de José da Victoria do Espírito Santo, 60 anos de idade, lavrador, casado, morador na Vila do Espírito Santo, natural da própria província, não sabendo ler e escrever, que ao ser inquirido sobre os fatos, nos diz

que não sabe que o escravo Ignácio estivesse em poder do réu presente; porquanto indo ele testemunha com o próprio senhor do mesmo escravo procurá-lo em casa do réu, não o encontraram, porém que tendo o visto em uma plantação de cana nas terras do réu e perguntado de quem era esta, respondeu-lhe José de 
Santana Roza que era pertencente ao escravo Ignácio, que ali trabalhava em terras que lhe dava o réu porque o seu senhor não lhe dava terras para trabalhar. ${ }^{35}$

O escravo Ignácio assim, por este último depoimento, já havia conquistado o direito de trabalhar para si nos finais de semana, já que fazia isto com o consentimento de seu senhor. No depoimento também consta que as terras eram dadas ao escravo Ignácio pelo liberto Angelo Marcellino e que a plantação de cana pertencia ao próprio escravo. Embora não tenhamos como saber com certeza quais os parâmetros das relações de trabalho que existiam entre Angelo Marcellino, que cedia a terra, e Ignácio, que nela trabalhava, o que é certo é que não se tratava de uma pura e simples utilização da capacidade de trabalho de Ignácio como escravo por Angelo Marcellino. Não se tratava, portanto, de simples sedução de escravo, como queria o queixoso.

Ao escravo Ignácio se aplica plenamente aquilo que Hebe Maria Mattos chama de politização da ação cotidiana do escravo. Sentindo-se no direito de ter acesso a terras para trabalhar nos finais de semana e não tendo esta sua expectativa atendida por seu senhor, Ignácio não esperou para agir. Sua ação se deu exatamente "no sentido de universalizar e retirar do arbítrio senhorial os canais costumeiramente instituídos de acesso a certo nível de estabilidade e autonomia que potencializassem, pelo menos enquanto possibilidade, o acesso ao pecúlio e finalmente à liberdade, através da compra da alforria" (Mattos, 1998, p.163). Ignácio fez mais ainda, providenciou, com a intermediação do liberto Angelo Marcellino e do escravo Clemente, junto ao filho de seu senhor, um inusitado "bilhete para procurar senhor".

O que Ignácio procurava fazer era dar sentido a uma experiência de liberdade que era sua, embora ele ainda fosse cativo. Ignácio parecia ver a liberdade de uma forma que, segundo Sidney Chalhoub, era muito comum entre escravos, libertos e mesmo senhores no Brasil escravista do século XIX. Tal visão de liberdade estava associada ao "viver sobre si", que podia significar: “'viver só', isto é, longe do senhor; e não pagar jornal ou dar 'contas de sua vida a pessoa alguma"' (Chalhoub, 1990, p.114). Ignácio se mostrou disposto a radicalizar tal visão de liberdade com a fuga e com a disposição de procurar ele mesmo um outro senhor que aceitasse as suas condições.

No último depoimento analisado, o de José da Victoria do Espírito Santo, também reaparece um personagem, que não depõe no inquérito, e que só aparece nele incidentalmente, mas de forma significativa. Trata-se do Sr. José de Sant'Anna Roza, que é quem informa ao depoente José da Victoria do Espírito Santo e ao senhor do escravo Ignácio, Antônio Gonçalves Laranja, que 
a plantação de cana pertencia ao escravo Ignácio, quando estes foram à casa do réu procurar o escravo e não o encontraram e nem ao próprio réu. Mas encontraram na casa do réu Angelo Marcellino o Sr. Sant'Anna Roza. Em outra ocasião se encontraram o Sr. Antônio Gonçalves Laranja e Sr. José de Sant'Anna Roza e, naquela ocasião, também estava presente Angelo Marcellino. Em seu depoimento, o Sr. Gonçalves Laranja nos diz que teve um desagradável encontro com os dois quando voltava de Cariacica, quando o ameaçaram e lhe disseram para desistir de procurar Ignácio. ${ }^{36}$

Mas quem era este José de Sant'Anna Roza? Pela queixa do Sr. Gonçalves Laranja, que abre o processo, ficamos sabendo que se trata nada mais nada menos do ex-senhor do réu Angelo Marcellino Pinto, e seu nome exato era José Joaquim de Sant'Anna Roza. ${ }^{37}$

A complexidade da realidade histórica, imperceptível por qualquer tentativa de generalização, é realmente fascinante. Estamos diante de um caso no qual um ex-escravo ajuda um escravo a fugir com a solidariedade de seu exsenhor. Trata-se de uma situação em que tudo o que sabemos de convencional sobre o que governava as relações senhor-escravo vai pelos ares. Ainda bem que nestes momentos ainda sentimos o chão firme sob nossos pés, porque podemos contar com uma fonte de tal qualidade.

Falta analisar o que significava para um escravo o fato de receber, ou obter, um "bilhete para procurar senhor", algo que também nunca vimos em tudo o que temos lido até então sobre a escravidão. Para isto examinaremos o fato, muito mais trágico, de um outro escravo, que também recebeu um bilhete desse tipo, embora em circunstâncias totalmente diferentes.

No dia 6 de julho de 1874 foi aberto um inquérito, solicitado pelo Sr. Joaquim José da Silva, para se verificar a identidade de um cadáver encontrado no mar, no local denominado ilha das Caiheiras, bem próximo a Vitória.

Pelo auto de exame de cadáver se constatou que se tratava de um homem de cor parda, cabelos carapinhos, barba cerrada, estatura regular e aparentando ter entre 30 e 35 anos. Todas as testemunhas que viram o cadáver o reconheceram, apesar de seu adiantado estado de putrefação, e disseram tratar-se de Francisco, escravo do Sr. Joaquim José da Silva, morador na própria ilha das Caiheiras. Ainda no auto de exame de cadáver, os peritos declararam que o cadáver em questão era o de Francisco José da Silva, pelo que ouviram dizer. Se o escravo realmente tinha sobrenome e, neste caso, se tratava de um escravo batizado, tal sobrenome é o de seu senhor. Conclui-se que a morte havia se dado por afogamento. Há também uma unanimidade nos depoimentos 
das testemunhas em concluírem que tal afogamento se deu por livre e espontânea vontade do escravo Francisco, ou seja, que se tratava de um suicídio.

O inquérito é conduzido então objetivando saber qual a razão ou quais as razões pelas quais Francisco decidiu dar fim à sua vida. A primeira razão a que somos levados a pensar que motivaria o suicídio de um escravo, e que deve também ter sido a primeira hipótese levantada por quem conduziu o inquérito, era o excesso de maus tratos de seu senhor. Em todas as inquirições, inclusive nos interrogatórios feitos a três libertos condicionais, parceiros de Francisco, tal pergunta era feita e todos respondem que Francisco era bem tratado por seu senhor.

Um sobrinho da mulher do senhor de Francisco, de nome Dionízio Pinto Furtado, de 40 anos de idade, viúvo, negociante, natural da própria província e morador na Ilha das Caiheiras, sabendo ler e escrever, declara em seu depoimento que nada lhe consta de problemas de Francisco com seu senhor, a não ser um episódio específico e recente, e que à exceção desse episódio, "nada lhe consta deste com seu senhor, pelo contrário ele era bom escravo". ${ }^{38}$

O episódio a que se refere o sobrinho da mulher do senhor de Francisco nos é narrado com detalhes pela primeira testemunha do inquérito, Cândido de Miranda Freitas, 52 anos de idade, filho legítimo de José de Anchieta [?], natural dessa cidade, empregado aposentado, morador na ilha das Caiheiras, sabendo ler e escrever, que nos diz em seu depoimento que

o próprio escravo, alguns dias antes de sua morte, dissera a ele testemunha que havia tido com o seu parceiro de nome Daniel, escravo também de seu senhor, uma contenda, e que nessa ocasião veio uma agregada da família e os repreendera a fim de não incomodarem a seu senhor que estava doente ao que respondera o dito escravo Francisco que ela com isso não se importasse, e que se retirasse porquanto eram meras desavenças entre parceiros que o seu senhor não precisava saber, e porque a mesma agregada de novo instasse para que se calassem, repetiu o dito escravo acrescentando que esta não era coisa alguma, e que se alguma coisa era, que o comprasse; a que respondeu a agregada que o não comprava porque não tinha dinheiro, ao que respondeu-lhe o escravo dizendo o que era feito do dinheiro que ela tinha roubado a seu senhor. E sendo seu senhor sabedor disso, mandou dizer ao escravo Francisco que fosse procurar senhor, que dele não queria mais saber como seu escravo. ${ }^{39}$

Ao ser perguntado se não tinha tido com o escravo alguma outra con- 
versação, e se mesmo durante esta de que falou, não lhe revelara o escravo mais alguma coisa, a testemunha acrescenta que

o mesmo escravo lhe havia dito também que não queria mais servir a seu dito senhor, ao que ele testemunha aconselhou-o, fazendo-lhe ver que outro senhor melhor este não encontraria. O escravo porém repetiu-lhe que não queria mais sujeitar ao seu senhorio, a fim de não dar gosto à mesma agregada de comer mais o seu dinheiro. ${ }^{40}$

A partir de uma questão menor com seu parceiro Daniel, Francisco tivera uma discussão com uma agregada de seu senhor, que acabou por ser o que levou seu senhor a mandar dizer a Francisco que fosse procurar outro senhor. Joaquim José da Silva não queria aborrecimentos com escravos seus. Já vimos o quanto era comum escravos serem alforriados com a alegação de que estavam sendo libertados pelos bons serviços prestados. Embora bons serviços também pudessem se constituir em obstáculos à alforria, ao tornarem o escravo muito desejado ou mesmo indispensável para seu senhor, o que Peter Eisenberg encontrou em suas fontes foi um caso único de um senhor que alforriou seu escravo pelos maus serviços prestados. Em 1884 o senhor do escravo Antônio, africano, alforriado com prestação de serviços, embora cobrando por sua generosidade a quantia de $100 \$ 000$, o libertou. Na verdade o remiu da prestação de serviços anteriormente acordada "com a condição de nunca pisar no meu sítio nem no bairro dos Passarinhos termo de Jundiaí, ficando com o direito de expulsá-lo de lá para fora, se por acaso aparecer lá algum dia". ${ }^{41}$

Francisco declara a Cândido de Miranda, quando este lhe diz que não encontraria senhor melhor, que não queria mais se sujeitar a este senhor "a fim de não dar gosto à mesma agregada de comer mais o seu dinheiro". Mas de que dinheiro estaria Francisco falando? À primeira vista parece se tratar do dinheiro de seu senhor. Mas para Francisco podia se tratar também de seu próprio dinheiro, e neste caso Francisco teria consciência de que era explorado pelo seu senhor, que com o seu trabalho sustentava essa agregada. Mesmo admitindo que o nível de consciência de Francisco não chegasse a tal ponto, para ele ao menos era claro que a agregada vivia à custa de seu senhor. Sua decisão de não querer mais servir a Joaquim José da Silva, sem contestar o conselho de Cândido de Miranda de que ele não encontraria melhor senhor, era, para Francisco, uma forma de evitar que a agregada continuasse a roubar o seu senhor. Francisco tinha consciência de haver uma relação entre o que 
entendia ser um roubo que praticava a agregada a seu senhor e o seu próprio trabalho. Quando diz que não queria mais se sujeitar a seu senhorio, ele revela sua decisão de cortar o mal pela raiz. Por enquanto, é apenas isto que podemos concluir. O que, aliás, não é pouco. Estamos de qualquer forma muito distantes de uma extravagante conclusão de que Francisco tenha se suicidado por um problema de consciência de classe. Não sabemos ainda por que ele se suicidou.

O depoimento de Daniel, liberto condicionalmente por Joaquim José da Silva, de 25 anos de idade, filho de Luiza, liberta, lavrador, natural da própria província e morador na ilha das Caiheiras, lança um pouco mais de luz nessa trajetória de trevas que devem ter sido os últimos dias de Francisco.

Daniel é o parceiro com quem Francisco tivera uma pequena desavença e que desencadeou a discussão com a agregada de seu senhor. Ele nos diz em seu depoimento

que o escravo morrera afogado, por ter seu senhor o mandado procurar novo senhor, e que dias antes de ter sido encontrado afogando-se [sic] por Manoel Pinto Pereira, tivera uma questão com ele respondente e por essa razão seu senhor incomodando-se lhe disse outra vez que procurasse senhor porque estando doente não queria escravos que o incomodasse. No dia seguinte ao que teve certeza de que com efeito o comendador José Ribeiro Coelho tinha ordem para vendê-lo, apareceu doente, disse este que de uma indigestão, e no dia seguinte foi o sucesso que acima referiu. ${ }^{42}$

Nesse depoimento de Daniel há informações que são indispensáveis para a nossa tentativa de descobrir o que motivou Francisco a tomar essa decisão radical. Daniel nos diz que no dia seguinte ao em que teve certeza de que o procurador de seu senhor, o comendador José Ribeiro Coelho, efetivamente tinha ordem para vendê-lo, Francisco apareceu doente, e no outro dia cometeu suicídio.

Ao tratar dos negócios da escravidão na Corte e de como às vezes esses negócios viravam pelo avesso, Sidney Chalhoub (1990) dá ênfase a quanto podia ser traumática para um escravo a mudança de senhor. Nesse seu trabalho são explicitadas as diferentes maneiras como os escravos procuravam influenciar seu destino quando das vendas e como, quando não conseguiam agir — seja no sentido de evitar a própria venda, seja no de influenciar na escolha do novo senhor — , adotavam estratégias mais radicais, como a fuga. 
O senhor de Francisco não apenas lhe ordenou que procurasse novo senhor. Ele providenciou por seu procurador para que fosse vendido.

Como no depoimento de Daniel, em vários outros depoimentos somos informados de que o Sr. Joaquim José da Silva resolveu dizer a Francisco que não o queria mais como escravo e que iria vendê-lo porque, estando doente, não queria escravos que o incomodassem.

Além de Daniel, depõem no processo dois outros parceiros de Francisco. São eles: Gregório, representando ter 25 anos mais ou menos, filho natural da escrava Francisca, casado, carpinteiro, liberto condicionalmente, morador na ilha das Caiheiras, e Caetano, de 40 anos de idade mais ou menos, solteiro, lavrador, natural da Costa da África, liberto condicionalmente por Joaquim José da Silva, morador na ilha das Caiheiras.

Como Daniel, também Gregório e Caetano eram libertos condicionais. Essa condição aparentemente a meio termo entre a escravidão e a liberdade carregava uma grande dose de ambigüidade. O liberto condicional Gregório reconhece o cadáver do escravo Francisco, "de seu senhor Joaquim José da Silva”. Gregório não está informando que o senhor de Francisco era Joaquim José da Silva, o que seria redundante. O que ele quer dizer é que Francisco era escravo de seu próprio senhor, o que significa que Gregório, apesar de ser liberto condicional, ainda se considerava como escravo. Gregório também diz que Francisco tivera uma questão com "um escravo seu companheiro". Mas Daniel, com quem Francisco tivera a questão, era também liberto condicional, e Gregório devia saber disso. ${ }^{43}$ Podemos perceber assim que esses libertos condicionais viam sua liberdade como uma espécie de promessa formalizada e que, enquanto a condição de liberdade não fosse cumprida, ainda se consideravam como escravos.

Daniel e Caetano também respondem da mesma forma que Gregório, quando perguntados se reconheciam o cadáver a eles apresentado, dizendo que Francisco era escravo "de seu senhor", Joaquim José da Silva. ${ }^{44}$

Agora já podemos juntar as peças de nosso quebra-cabeça. São elas: a doença do senhor de Francisco, a condição dos parceiros de Francisco e, por último, a decisão pela sua venda. $\mathrm{O}$ incidente com a agregada não é uma peça indispensável.

Francisco tinha pelo menos três parceiros que já haviam sido libertados condicionalmente pelo seu senhor Joaquim José da Silva. Qual seria a condição sob a qual haviam sido libertados Daniel, Gregório e Caetano? Muito provavelmente a de servirem a seu senhor até a morte deste.

Joaquim José da Silva estava doente, e são várias as testemunhas que ti- 
nham conhecimento dessa doença. Isso nos leva a crer que tal doença já vinha de algum tempo, e que não se tratava de um simples resfriado.

Certamente Francisco tinha expectativas de se tornar liberto como o foram Daniel, Gregório e Caetano, e, como estes, também devia contar com a liberdade definitiva para breve, com a morte de seu senhor.

Francisco era tido como um escravo de bom comportamento e esperava ser premiado por isto. Sua venda agora significava começar tudo de novo, e ele não suportou tal idéia.

Para Francisco a vida só fez sentido enquanto ele acreditava na liberdade. Quando essa ilusão se desfez, ele decidiu pôr fim à própria vida.

Sua decisão radical e desesperada pelo suicídio pode ser explicada por essa conjunção de fatores de seu destino. Que ele tenha decidido morrer entrando pela vastidão do mar adentro, pode reforçar a nossa interpretação ou não, sendo apenas uma imagem um tanto poética, ou mesmo piegas, de sua morte, se é que pode haver poesia na morte. Abusiva ou não essa imagem, o fato é que para Francisco, para quem a liberdade devia parecer estar próxima, essa foi afinal a única liberdade possível.

O escravo Ignácio conseguiu, iludindo ou não o filho de seu senhor, um "bilhete para procurar senhor" e foi cuidar de sua vida. O escravo Francisco recebeu um bilhete do mesmo tipo e foi cuidar... de dar fim à própria vida. As experiências de vida e de busca por espaços de liberdade por estes dois escravos, mais as várias experiências e expectativas de liberdade por parte dos libertos da Freguesia de São João de Cariacica, mostram que o cotidiano da escravidão era povoado de esperanças, em relação ao que podia se tornar a vida de cada um, e também de desventuras. Uns conseguiam tanto alimentar seus sonhos como às vezes absorver eventuais frustrações, outros não. Um prosaico "bilhete para procurar senhor" podia ser um recomeço ou um passo adiante para alguns, e um fim para outros.

\section{NOTAS}

${ }^{1}$ Cartório Ronconi, Registro de carta de liberdade, 11.02.1884, fl. 18. Nos registros de cartas de liberdade originários do Cartório Sede da Freguesia de São João de Cariacica, no período entre 1872 e 1887, que pesquisamos no Cartório Ronconi, bairro de Itacibá, em Cariacica, ES, tanto as caixas como os livros não estão numerados. Adotamos então a notação acima 'Registro de carta de liberdade', seguida da data e do número da folha, pelos quais é possível localizar estas fontes já que é pequeno o número de caixas e livros referentes a esse período. Trata-se também dos únicos registros de cartas de alforria disponíveis, ou seja, em tal cartó- 
rio os primeiros registros são de 1872. Aproveitamos a oportunidade para agradecer à tabeliã responsável pelo Cartório Ronconi, Sra. Gerusa Corteletti Ronconi, e a seus funcionários pela disponibilidade e gentileza para conosco quando de nossa pesquisa.

${ }^{2}$ Brasil. Recenseamento do Brasil de 1872, Espírito Santo, p.76-7.

${ }^{3}$ SCHWARTZ, Stuart B. Escravos, roceiros e rebeldes. Tradução de Jussara Simões. Bauru (SP): Edusc, 2001, p.189.

${ }^{4}$ RUSSELL-WOOD, A. J. R. Escravos e libertos no Brasil colonial. Tradução de Maria Beatriz Medina. Rio de Janeiro: Civilização Brasileira, 2005, p.77.

${ }^{5}$ Cartório Ronconi, Registro de Carta de Liberdade, 10.11.1875, fl. 33.

${ }^{6}$ Cartório Ronconi, Registro de Carta de Liberdade, 14.12.1876, fl. 1.

${ }^{7}$ EISENBERG, Peter L. Ficando livre: as alforrias em Campinas no século XIX (1987). In: . Homens esquecidos: escravos e trabalhadores livres no Brasil, séculos XVIII e XIX. Campinas (SP): Ed. Unicamp, 1989, p.274.

${ }^{8}$ MATTOSO, Kátia M. Q. A carta de alforria como fonte complementar para o estudo da rentabilidade da mão-de-obra escrava urbana (1819-1888) (1976). In: Da revolução dos alfaiates à riqueza dos baianos no século XIX: itinerário de uma historiadora. Salvador: Corrupio, 2004, p.193.

${ }^{9}$ EISENBERG, Peter L. Ficando livre: as alforrias em Campinas no século XIX (1987). In: Homens esquecidos: escravos e trabalhadores livres no Brasil, séculos XVIII e XIX. Campinas (SP): Ed. Unicamp, 1989, p.298.

${ }^{10}$ SCHWARTZ, Stuart B. Escravos, roceiros e rebeldes. Trad. Jussara Simões. Bauru (SP): Edusc, 2001, p.190-1.

${ }^{11}$ BELLINI, Lígia. Por amor e interesse: a relação senhor-escravo em cartas de alforria. In: REIS, João José (Org.) Escravidão e invenção da liberdade: estudos sobre o negro no Brasil. São Paulo: Brasiliense; Brasília: CNPq, 1988, p.85.

${ }^{12}$ Cartório Ronconi, Registro de Carta de Liberdade, 15.09.1884, fl. 13.

${ }^{13}$ Cartório Ronconi, Registro de Carta de Liberdade, 28.10.1886, fl. 20.

${ }^{14}$ SILVA, Eduardo. Fugas, revoltas e quilombos: os limites da negociação. In:

REIS, João José. Negociação e conflito: a resistência negra no Brasil escravista. São Paulo: Companhia das Letras, 1989, p.71.

${ }^{15}$ Cartório Ronconi, Registro de Carta de Liberdade, 12.04.1873, fl. 29.

${ }^{16}$ Cartório Ronconi, Registro de Carta de Liberdade, 1878, fl. 90. 
${ }^{17}$ MALHEIRO, Perdigão. A escravidão no Brasil: ensaio histórico, jurídico, social. Petrópolis: Vozes/INL, 1976. 2v.

${ }^{18}$ Cartório Ronconi, Registro de Carta de Liberdade, 25.04.1873, fl. 31.

${ }^{19}$ Cartório Ronconi, Registro de Carta de Liberdade, 16.12.1876, fl. 39.

${ }^{20}$ Cartório Ronconi, Registro de Carta de Liberdade, 29.12.1877, fl. 5.

${ }^{21}$ MATTOSO, Kátia M. Q. Testamentos de escravos libertos na Bahia no século XIX: uma fonte para o estudo das mentalidades (1979). In: Da revolução dos alfaiates à riqueza dos baianos no século XIX: itinerário de uma historiadora. Salvador: Corrupio, 2004, p.230.

${ }^{22}$ Cartório Ronconi, Registro de Carta de Liberdade, 22.09.1883, fl. 49.

${ }^{23}$ Cartório Ronconi, Registro de Carta de Liberdade, 01.05.1877, fl. 84.

${ }^{24}$ CHALHOUB, Sidney. Visões da liberdade: uma história das últimas décadas da escravidão na Corte. São Paulo: Companhia das Letras, 1990, p.134.

${ }^{25}$ BELLINI, Lígia. Por amor e interesse: a relação senhor-escravo em cartas de alforria. In: REIS, João José (Org.) Escravidão e invenção da liberdade: estudos sobre o negro no Brasil. São Paulo: Brasiliense; Brasília: CNPq, 1988, p.84.

${ }^{26} \mathrm{KARASCH}$, Mary C. A vida dos escravos no Rio de Janeiro: 1808-1850. Trad. Pedro Maia Soares. São Paulo: Companhia das Letras, 2000, p.470.

${ }^{27}$ MATTOS, Hebe Maria. Das cores do silêncio: os significados da liberdade no sudeste escravista - Brasil, séc. XIX. 2.ed. Rio de Janeiro: Nova Fronteira, 1998, p.34.

${ }^{28}$ Apees (Arquivo Público do Estado do Espírito Santo), Inquérito n 384, 1872, fl. 13.

${ }^{29}$ Apees, Inquérito $\mathrm{n}^{\circ} 384,1872$, fls. 5, 13 e 14.

${ }^{30}$ Apees, Inquérito n 384, 1872, fl. 15.

${ }^{31}$ Apees, Inquérito n ${ }^{\circ} 384,1872$, fl. 15-16.

${ }^{32}$ Apees, Inquérito $n^{\circ} 384,1872$, fl. 16.

${ }^{33}$ Apees, Inquérito $n^{\circ} 384,1872$, fls. 23-24.

${ }^{34}$ Apees, Inquérito n ${ }^{\circ} 384,1872$, fls. 24-25.

${ }^{35}$ Apees, Inquérito n 384, 1872, fl. 33.

${ }^{36}$ Apees, Inquérito n ${ }^{\circ} 384,1872$, fl. 14.

${ }^{37}$ Apees, Inquérito $\mathrm{n}^{\circ} 384,1872$, fl. 5.

${ }^{38}$ Apees, Inquérito $n^{\circ} 452,1874$, fl. 13. 
Geraldo Antonio Soares

${ }^{39}$ Apees, Inquérito $\mathrm{n}^{\circ} 452,1874$, fl. 8.

${ }^{40}$ Apees, Inquérito ${ }^{\circ} 452,1874$, fls. 8-9.

${ }^{41}$ EISENBERG, Peter L. Ficando livre: as alforrias em Campinas no século XIX (1987). In: Homens esquecidos: escravos e trabalhadores livres no Brasil, séculos XVIII e XIX. Campinas (SP): Ed. Unicamp, 1989, p.297.

${ }^{42}$ Apees, Inquérito $\mathrm{n}^{\circ} 452,1874$, fl. 19.

${ }^{43}$ Apees, Inquérito $n^{\circ} 452,1874$, fl. 18.

${ }^{44}$ Apees, Inquérito $\mathrm{n}^{\circ} 452,1874$, fls. 19-20. 